\title{
Efficacy of FNAC in Diagnosis of Breast Lumps - A Retrospective Study
}

\author{
Oankar Kumar Maurya ${ }^{1}, \operatorname{Richa}^{2}$, Manohar Lal $^{3}$, Prashant Kumar \\ ${ }^{1}$ Assoc. Prof. \& H.O.D., Dept. of Surgery, ${ }^{2}$ Senior Resident, Dept. of E.N.T., \\ ${ }^{3}$ Asst. Professor, Dept. of Pathology, ${ }^{4}$ Senior Resident, Dept. of Surgery, \\ ${ }^{1,2,3,4}$ Nalanda Medical College \& Hospital, Patna, Bihar, India \\ Corresponding Author: O. K. Maurya
}

\begin{abstract}
Background: FNAC is an established and highly accurate method for diagnosis of breast lesions. Its further advantage is to give rapid diagnosis, cost-effectiveness, excellent patient acceptance and minimal or no morbidity. The study aimed to diagnose various breast masses before operation by FNAC and to compare the result of FNAC with histopathological study to assess the efficacy of FNAC.

Materials and Methods: The study entitled "Efficacy of FNAC in diagnosis of Breast Lumps" is a retrospective study conducted in department of surgery with collaboration of pathology department at Nalanda Medical College and Hospital, Patna during the period of July 2017 to December 2019. During this period, 150 FNAC cases were selected for study.
\end{abstract}

Results: Fibroadenoma was the most commonly diagnosed entity in benign breast lesions, followed by fibrocystic disease. Among malignant lesions, infiltrating ductal carcinoma was the most common. The overall diagnostic accuracy of FNAC in benign breast lesions was $94.59 \%$. The fibroadenomas were correctly diagnosed in $92.96 \%$ cases. There were $5.41 \%$ false negative results in our series. There was no false positive result giving specificity of $100 \%$.

Conclusion: FNAC is an inexpensive, simple, safe and readily acceptable procedure to the patient and plays main role to provide rapid and accurate diagnosis of breast lumps. FNAC enables us to differentiate benign from malignant lesions with high sensitivity, specificity and diagnostic accuracy.
Keywords: Breast Lump, FNAC, HPE:

Histopathological Examination.

\section{INTRODUCTION}

Fine needle aspiration cytology (FNAC) of breast was first used in the 1930s by Martin \& Ellis and by Stewart at Memorial Hospital ${ }^{[1,2,3]}$, followed in the late 1940 s and early 1950 s by Adair ${ }^{[4]}$ and Godwin ${ }^{[5]}$. Breast lump is a matter of worry to patient as well as clinician, hence need of reliable and quick method for correct diagnosis.

FNAC is an established and highly accurate method for diagnosis of breast lesions. Its further advantage is to give rapid diagnosis, cost-effectiveness, excellent patient acceptance and minimal or no morbidity ${ }^{[6]}$. The use of core biopsy $(\mathrm{CB})$ is being increasingly advertised but its procedure is more cumbersome, expensive and time consuming as compared to FNA procedure ${ }^{[7,8,9]}$ Core biopsy or Trucut needle biopsy is not widely used because of its complications, interpretation and time consuming result; therefore palpable breast lesions can be accurately diagnosed by triple test only i.e. physical examination, mammography and FNAC ${ }^{[10]}$.

FNAC of breast has average sensitivity of $87 \%$, specificity of $98-100 \%$, negative predictive value of $87-99 \%$ and the efficiency of $89-99 \%{ }^{[11,12,13]}$. False positive results in the literature are reported to be approximately $4 \%{ }^{[14]}$. 
In an effort to diagnose various breast masses before operation, we conducted a retrospective study to assess the accuracy of FNAC and compared the result with histopathological study.

\section{MATERIALS AND METHODS}

A retrospective study was conducted in department of surgery with collaboration of pathology department at Nalanda Medical College and Hospital, Patna during the period of July 2017 to December 2019. During this period, 150 FNAC cases were selected for study.

FNAC was done by the cytopathologists using a 23 gauge needle attached to a $10 \mathrm{ml}$ syringe with proper aseptic precautions without local anaesthesia. Material spread on glass slide was wet fixed in $95 \%$ methanol and was air dried for staining with two stains Haematoxylin and Eosin $(\mathrm{H} \& \mathrm{E})$ and Papanicolaou(Pap) stains.

Slides were examined under microscope by cytopathologists and were interpreted as benign/ suspicious of malignancy / malignant tissues present / inadequate or unsatisfactory.

The benign lesions were further categorized using the morphologic criteria described by Zajicek (1974) [14] into fibroadenoma, mammary dysplasia, galactocele, granulomatous, cystosarcoma phylloides (benign), duct hyperplasia, fat necrosis and mastitis.

A diagnosis of fibroadenoma was made where monolayered sheets of ductular epithelial cells were seen. Cells showed round to oval nuclei with coarse chromatin and many bipolar naked nuclei in background. Fibroadenosis was diagnosed when sheets of duct epithelial cells showed mild pleomorphism, foam cells and porcine cells.

'Suspicious of malignancy' report was given in cases where cytologic findings were highly suggestive but malignancy was not confirmed. Reports with 'malignant tissues present' were given where definite malignant cells were recognized. Cases in which none or very few cells were obtained were reported as 'inadequate' or 'unsatisfactory'.

All cases with FNAC report showing benign breast lesions except mastitis and breast abscess were operated as open excisional biopsy. Cases with malignant report were subjected to modified radical or simple mastectomy. Breast lumps reported as 'suspicious of malignancy' were subjected to lumpectomy with $2 \mathrm{~cm}$ clear margin all around the lump. Tissues removed in all cases were subjected to histopathological examination. The histopathological findings were correlated with those of FNAC.

\section{RESULT}

A total of 150 patients with breast lump were subjected to FNAC during the period of July 2017 to December 2019. Satisfactory aspirates were available in 142 cases $(94.66 \%)$. Out of 142 satisfactory aspirates, $119(83.8 \%)$ were reported as benign breast lesions, $17(11.97 \%)$ as malignant breast lesions, $6(4.22 \%)$ as suspicious of malignancy. Rest $8(5.33 \%)$ cases were reported as unsatisfactory. Among 119 cytologically benign breast lesions, HPE was done in 112 cases, in which 106 cases proved to be benign and 6 cases malignant. All 17 cytologically malignant cases were subjected to histopathological examination and all were proved to be malignant. Among 6 suspicious cases, 5 cases were put to histopathological examination, 1 was proved to be benign whereas 4 malignant. Among unsatisfactory aspirates, 6 put to histopathological examination, 5 were found to be benign and 1 malignant. Table I shows the cytological diagnosis of these along with the histological correlation.

Among 119 cytologically diagnosed benign breast lesions, fibroadenoma accounted for 71 cases, fybrocystic disease 24, galactocele 3, granulomatous lesions 1 , benign phylloides 2 , duct hyperplasia 4 , acute nonspecific mastits 3 , breast abscesses 4 , fat necrosis 1 and benign breast lesions 
without a specific diagnosis in 6 cases.

TABLE I: Cyto-histological correlation of all breast lesions

\begin{tabular}{|l|l|l|l|l|}
\hline & \multicolumn{3}{l|}{ Histological Diagnosis } \\
\hline Cytological Diagnosis & No of cases & Histology available & Benign Breast lesions & Malignant Breast lesions \\
\hline Benign Breast lesions & 119 & 111 & 105 & 6 \\
\hline Malignant Breast lesions & 17 & 17 & 0 & 17 \\
\hline Suspicious & 6 & 5 & 1 & 4 \\
\hline Unsatisfactory & 8 & 6 & 5 & 1 \\
\hline Total & 150 & 139 & 111 & 28 \\
\hline
\end{tabular}

Out of 71 cytologically diagnosed fibroadenomas, 66 cases were diagnosed as fibroadenoma, 3 as fibrocystic disease, 1 as cystosarcoma phylloides (benign) and 1 proved to be malignant on histopathological examination. Out of 24 cytologically diagnosed fibrocystic disease, 4 proved to be fibroadenoma, 18 fibrocystic disease and 2 proved to be malignant on histopathological examination. Details of cyto-histological correlation are summarized in Table II.

TABLE II: Cyto-histological correlation of benign lesions

\begin{tabular}{|c|c|c|c|c|c|c|c|c|}
\hline \multicolumn{2}{|l|}{ Cytological Diagnosis } & \multicolumn{7}{|c|}{ Histological Diagnosis } \\
\hline & $\begin{array}{l}\text { No of } \\
\text { cases }\end{array}$ & $\begin{array}{l}\text { Fibro } \\
\text { adenoma }\end{array}$ & $\begin{array}{l}\text { Fibrocystic } \\
\text { disease }\end{array}$ & $\begin{array}{l}\text { Cystosarcoma } \\
\text { Phylloides } \\
\text { (benign) } \\
\end{array}$ & Granulomatous & $\begin{array}{l}\text { Duct } \\
\text { Papilloma }\end{array}$ & $\begin{array}{l}\text { Fat } \\
\text { necrosis }\end{array}$ & Malignant \\
\hline Fibroadenoma & 71 & 66 & 3 & 1 & - & - & - & 1 \\
\hline Fibrocystic disease & 24 & 4 & 18 & - & - & - & - & 2 \\
\hline Galactocele & 3 & - & - & - & - & 2 & - & 1 \\
\hline Granulomatous & 1 & - & - & - & 1 & - & - & - \\
\hline $\begin{array}{l}\text { Cystosarcoma } \\
\text { phylloides(benign) }\end{array}$ & 2 & - & - & 2 & - & - & - & - \\
\hline Duct hyperplasia & 4 & - & - & - & - & 3 & - & 1 \\
\hline Fat necrosis & 1 & - & - & - & - & - & 1 & - \\
\hline $\begin{array}{l}\text { Benign breast lesions } \\
\text { without specific } \\
\text { diagnosis }\end{array}$ & 6 & - & 4 & - & - & 1 & - & 1 \\
\hline Total & 112 & 70 & 25 & 3 & 1 & 6 & 1 & 6 \\
\hline
\end{tabular}

All malignant lesions were subjected to histopathological examination. Among 17 malignant breast lesions, ductal carcinoma accounted for 15 cases, lobular carcinoma for 1 , and metaplastic carcinoma for 1 case. Cyto-histological correlation of malignant lesions are given in Table III.

TABLE III: Cyto-histological correlation of malignant lesions

\begin{tabular}{|l|l|l|l|l|l|l|l|}
\hline \multicolumn{2}{|l|}{ Cytological Diagnosis } & \multicolumn{2}{l}{ Histological diagnosis } \\
\hline & $\begin{array}{l}\text { No. of } \\
\text { cases }\end{array}$ & $\begin{array}{l}\text { Invasive Ductal } \\
\text { Ca }\end{array}$ & $\begin{array}{l}\text { Tubular } \\
\text { Ca }\end{array}$ & $\begin{array}{l}\text { Medullary } \\
\text { Ca }\end{array}$ & $\begin{array}{l}\text { Mucinous } \\
\text { Ca }\end{array}$ & $\begin{array}{l}\text { Lobular } \\
\text { Ca }\end{array}$ & Metaplastic \\
\hline Ductal Ca & 15 & 13 & 1 & 1 & - & - & - \\
\hline Lobular Ca & 1 & - & - & - & - & 1 & - \\
\hline $\begin{array}{l}\text { Metaplastic } \\
\text { Ca }\end{array}$ & 1 & - & - & - & - & - & 1 \\
\hline Total & 17 & 13 & 1 & 1 & - & 1 & 1 \\
\hline
\end{tabular}

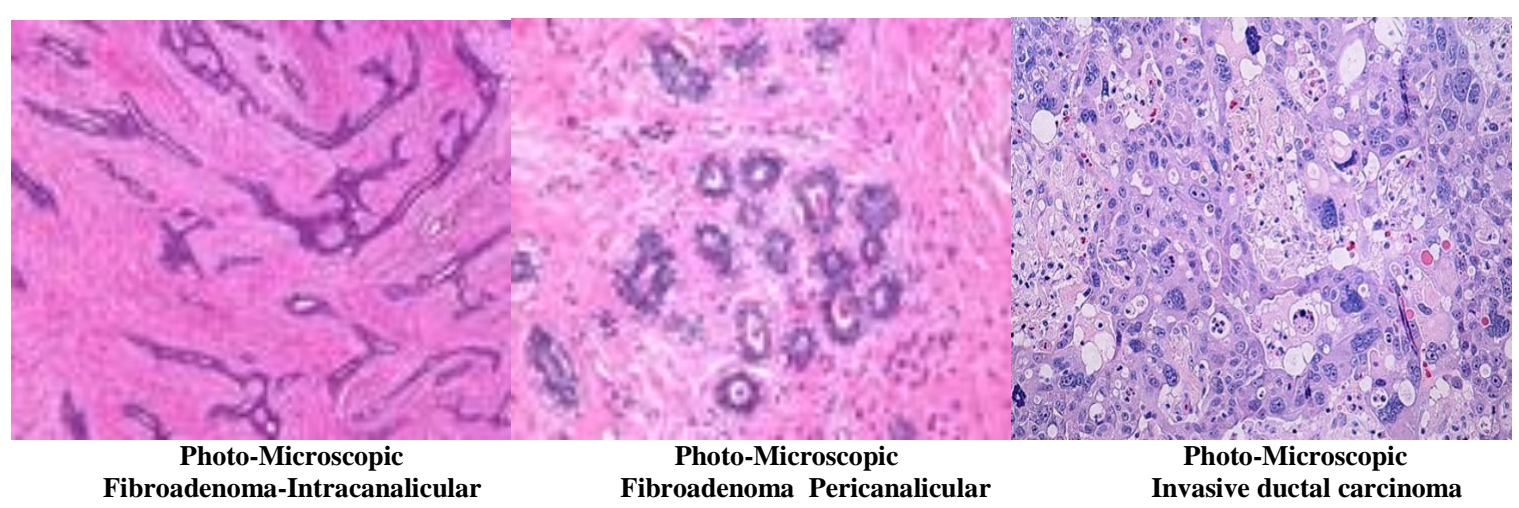




\section{DISCUSSION}

In the present study, fibroadenoma was the most commonly diagnosed entity in benign breast lesions (N71, 47.33\%), followed by fibrocystic disease (N24, 16\%). These findings correlated well with other authors ${ }^{[15,16,17]}$. Among malignant lesions, infiltrating ductal carcinoma was the most common, which correlated well with many authors ${ }^{[15,16,17]}$.

The incidence of benign lesions in the present study were similar to the observation made by Ishita pant et al ${ }^{[16]}$, Rocha et al ${ }^{[18]}$, Ashwin et al ${ }^{[19]}$, whereas the incidence of malignant cases were in comparison with the observation of Y.D. Choi et al ${ }^{[20]}$ as depicted in Table IV.

Table IV

\begin{tabular}{|l|c|c|c|c|c|}
\hline & Rocha18 & (1997) Ishita pant16 & $\mathbf{( 2 0 0 3 )}$ Y.D. Choi20 & (2004) Ashwin19 & (2015) Present study \\
\hline Period & 4 Year & 1 Year & 4 Year & 2 Year & 2.5 Year \\
\hline Breast lesions & & & & & \\
\hline Benign & $641(76.58 \%)$ & $85(68 \%)$ & $981(75.64 \%)$ & $319(77.2 \%)$ & $119(79.33 \%)$ \\
\hline Malignant & $99(11.83 \%)$ & $25(20 \%)$ & $182(14.03 \%)$ & $76(18.4 \%)$ & $17(11.86 \%)$ \\
\hline
\end{tabular}

The overall diagnostic accuracy of FNAC in benign breast lesions was $94.59 \%$. This compares well with the reported series $97.1 \%^{[21]}, 93.66 \%^{[22]}, 97.87 \%{ }^{[23]}$, and $94 \%$ [24]. The fibroadenomas were correctly diagnosed in $92.96 \%$ of 71 histologically documented cases in our series.

There were $6(5.41 \%)$ false negative cases in our series. There was no false positive result giving specificity of $100 \%$. False negatives in breast aspirates may be due to sampling error or judgment error. In the hands of experienced cytopathologists the latter should be minimal. A repeat aspirate improves the accuracy in clinically doubtful cases, but not even a succession of negative needle biopsies ensures that a lesion is benign. Excision biopsy should therefore be performed in all clinically doubtful but cytologically negative cases.

\section{CONCLUSION}

FNAC is an inexpensive, simple, safe and readily acceptable procedure to patient and plays main role to provide rapid and accurate diagnosis of breast lumps. FNAC enables us to differentiate benign from malignant lesions with high sensitivity, specificity and diagnostic accuracy. Benign and malignant interpretations are highly predictive but must be used only in the context of other diagnostic modalities. Suspicious lesions require further investigation.
Diagnostic errors with subsequent inappropriate clinical decisions can be best avoided if clinician use the Triple diagnostic procedure of clinical examination, mammography/ultrasonography and FNAC which increase the accuracy for diagnosis of breast lesions.

\section{Acknowledgement: None}

\section{Conflict of Interest: None}

\section{Source of Funding: None}

\section{Ethical Approval: Approved}

\section{REFERENCES}

1. Martin HE, Ellis E B. Biopsy by needle puncture and aspiration. Ann Surg.1930 Aug;92(2);169-81.

2. Martin HE, Ellis E B. Aspiration Biopsy. Surgery, Gynaecology and Obstetrics 1934; 59:578-589.

3. Stewart F.W. The diagnosis of tumors by aspiration. AM J Pathol 1933; 9:801-12.

4. Adair FE. Surgical problems involved in breast cancer. Ann R Coll Surg Engl 1949; 4;360-380.

5. Godwin JT, Aspiration biopsy: technique and application. Ann NY Acad Sci 1956; 63:1348-1373.

6. Silverman JFI, Lannin DR, O'Brien K, et al.The triage role of fine needle aspiration biopsy of palpable breast masses. Diagnostic accuracy and cost effectiveness. Acta Cytol.1987 Nov-Dec; 31(6): 731-6. 
7. Rubin M, Horiuchi K, Joy N, et al. Use of fine needle aspiration for solid breast lesions is accurate and cost-effective. American Journal of Surgery.1997;174(6):694-698.

8. Berner A, Sigstad E, Reed W, Risberg B. Fine needle aspiration cytology or core biopsy when diagnosing tumours of the breast. Tidsskrift for den Norske Laegeforening. 2003;123(12):1677-1679.

9. Lieu D. Value of cytopathologist-performed ultrasound -guided fine needle aspiration as a screening test for ultrasound -guided coreneedle biopsy in nonpalpable breast masses. Diagnostic Cytopathology. 2009;37(4):262269.

10. Ishikawa T, Hamaguchi $\mathrm{Y}$, Tanabe M, et al. False-positive and false-negative cases of fine- needle aspiration cytology for palpable breast lesions. Breast cancer. 2007,14(4):388-392.

11. Norton LW, Dans JR, Wiens JL, et al. Accuracy of aspiration cytology in detecting breast cancer. Surgery 1984;96: 806-814.

12. Silverman JF, Diagnostic accuracy, cost effectiveness and triage role of fine- needle aspiration biopsy in the diagnosis of palpable breast masses. Breast J 1985;1:3-8.

13. Silverman JFI, Finley JL, O'Brien KF, et al; Diagnostic accuracy and role of immediate interpretation of fine- needle aspiration biopsy specimens from various sites. Acta Cytol. 1989 Nov-Dec;33(6);791-6.

14. Zajicek J. : Monographs in clinical cytology(Aspiration Biopsy Cytology, Part I), Vol 4 Basel,Sharger, 1974, pp.140.

15. Pinto RG, Kulwant S. A statistical analysis of fine needle aspiration biopsies in palpable benign(neoplastic and non neoplastic) breast lesions. J Cytol 2004;21:64-7.

16. Ishita P, Singh PK. Cytomorphologic study of palpable breast lesions and histopathologic correlation. J Cytol 2003; 20: 129-32.

17. Swapan KR, Ranjana B. FNAC of breast with reference to topography and nuclear grading in malignant lesions. J Cytol 2002; 19:187-92.

18. Premila De Souza Rocha, N S Nadkarni, S Menezes. Fine needle aspiration biopsy of breast lesions and histopathologic correlation. An analysis of 837 cases in 4 years.Acta Cytol 1997;41(3):705-712.

19. Ashwin Pattan shetty Khageshan et al, Diagnostic Utility of FNAC in Evaluation of Breast masses.International Journal of Recent Scientific Research Vol 6, Issue 8, 5827-5831, August 2015.

20. Y D Choi, Y H Choi, J H Lee, J H Nam, S W J uhng, C Choi. Analysis of fine needle aspiration cytology of breast: A review of 1297 cases and correlation with histological diagnosis. Acta Cytol 2004; 48 (6): 801806.

21. Zajicek J, Casperssan T, Jakoberson P, et al.: Cytologic diagnosis of mammary tumours from aspiration biopsy smearscomparison of cytologic and histologic findings in lesions and diagnostic use of cytophotometry. Acta Cytol, 1970, 14:370376.

22. Starvric GD, Toveev DT, Kaftandijive DR and Novak J.J.: Aspiration biopsy cytologic method in diagnosis of breast lesions. Acta Cytol, 1973, 17:188-190.

23. Bansal R, Sunkaran V and Veliath AJ. : Role of the needle aspiration cytology in the diagnosis of breast lumps and its histopathological correlation. Journal of Cytology, 1985, 2:62-66.

24. Gupta SK, Raje R, Rajwanshi A, Choudhary T, Bannerjee CK and Kaushik SP.:Role of fine needle aspiration biopsy(FNAB) in diagnosis and management of benign breast lesions. Bul. P.G.I.1984,18:82-86.

How to cite this article: Maurya OA, Richa, Lal $M$ et.al. Efficacy of FNAC in diagnosis of breast lumps- a retrospective study. International Journal of Research and Review. 2021; 8(9): 13-17. DOI: https://doi.org/10.52403/ijrr. 20210903 